sledovat, jakým směrem Německo, Francie, Itálie a další země vykročí směrem z pasti eura.

Hodnocená kniha ve formě rozhovoru vtáhne čtenáře do děje a jsem přesvědčen, že každý bude mít chut' si ji přečíst „,v jednom zátahu“. Text se dobře čte a nikde nedrhne i díky profesionálně odvedenému překladu prof. Karla Dyby. Zvolený zpo̊sob výkladu ve formě rozhovoru s sebou nese i nečetné drobné nedostatky - některé myšlenky se vícekrát opakují a některé části jsou naopak méně vyargumentované (napřs. str. 145-147). Celkově se však jedná o knihu, kterou si určitě se zájmem přečte i ekonom, který jinak čte pouze impaktované články a working papery centrálních bank.

\title{
NEJLEPŠÍ PUBLIKACE ZA ROK 2015 PODLE FINANCIAL TIMES, THE ECONOMIST A SKUPINY BLOOMBERG
}

\section{Samy Metrah*}

\section{John Kay: Other People's Money: The Real Business of Finance}

\author{
Public Affairs, 2015. 1. vydání. 352 stran. ISBN: 978-1610396035.
}

V posledních letech se obnovila debata o struktuře soudobých finančních systémů a jejich stabilitě. Stejně tak vyvstala debata o roli, jež by měly plnit soudobé regulatorní orgány při zajištění jejich bezproblémové činnosti. V tomto smyslu recenzovaná publikace poskytuje kritické zhodnocení fungování finančních trhů, jejich role jakožto primárního původce či nejspíše viníka nejdelší ekonomické krize posledních let, a v neposlední řadě také poskytuje návrhy na jejich reformu. Nicméně autor této recenze je na vážkách, zdali se kniha Other People's Money: The Real Business of Finance dá považovat za objektivní, tj. ,pozitivistickou“, kritiku dané problematiky, nebot' jednotlivé kapitoly oscilují svým obsahem od relativně „suché“ analýzy chování a motivací účastníků finančních trhů k novodobé verzi Malleus Maleficarum s tím rozdílem, že předmětem jsou ,alchymisté“ bankovní a finanční profese, jež své unikátní postavení, které jim propůjčují finanční trhy, využívají ke svým krátkozrakým a sobeckým zájmům. Nicméně svým osobitým způsobem autor, profesor John Kay, umožňuje náhled na fungování systému, jemuž se v soudobých hospodářstvích přikládá tak vysoký význam. Rozhodně musíme zmínit přijetí této knihy, nebot' získala ocenění nejlepší publikace za rok 2015 dle Financial Times, The Economist a skupiny Bloomberg.

John Kay je profesorem ekonomie na St. John's College a v současné době hostujícím profesorem na London School of Economics and Political Science. Jak sám uvádí, jeho životní zkušenosti ho zavedly nejen na akademickou půdu, ale také do zasedacích

\footnotetext{
* $\quad$ Samy Metrah (s.metrah@gmail.com), Vysoká škola ekonomická v Praze, Fakulta financí a účetnictví.
} 
místností velkých korporací a poradních orgánů státní správy Spojeného království. Recenzovaná kniha by se dala chápat jako finální článek v autorově publikační aktivitě, jež se primárně zaměřuje právě na negativní aspekty fungování finančních trhů. Není bez zajímavosti, že ve své publikační činnosti úzce spolupracoval s Mervynem A. Kingem, bývalým guvernérem Bank of England.

Kniha je členěna do třech samostatných částí, jež se postupně zabývají historií a evolučním vývojem finančních trhů a rolí bankovních institucí vůbec, analýzou funkcí, které by tyto trhy a instituce měly plnit, a návrhem možných reforem vedoucích k nápravě jejich pokřivené činnosti. Autorův osobitý styl vyniká již v předmluvě, jejímž obsahem je podobenství o volovi (zvíreti). To pojednává o sázkách obyvatel imaginárního společenství na odhad váhy vola. Povídka končí situací, kdy hráči rezignují na jakékoliv vyhodnocení hledisek (fundamentů) determinujících hmotnost zvířete, ale pouze se snaží odhadnout, co si myslí ostatní účastníci; zatímco zvíře umírá, nebot' se na něj zapomnělo. Samožrejmě, že zbytek knihy se nese v daleko serióznějším duchu, nicméně tato pejorativní alegorie o fungování finančních (efektivních) trhů je protkána celou publikací. Úvod poskytuje obecný náčrt problémů, o nichž se pojednává dále; jmenovitě se jedná o čtyři hlavní funkce, jež by finanční trhy měly plnit pro reálné hospodářství - zajištění platebního styku, zajišt'ování efektivní alokace úspor, mezigenerační přesuny bohatství a poskytnutí prostředků k překonání nejistoty jak (fyzickým) osobám, tak i ekonomicky činným subjektům; nereálná a především iluzorní ziskovost účastníků na finančních trzích; diskuse důvodů, proč se finanční sektory těší výjimečnému postavení; a finálně uzurpování vytvořených hodnot (produktu) v „reálném“ hospodářství finančními konglomeráty.

První, nejdelší kapitola mapuje historický vývoj bankovnictví jako instituce, jejíž původní a též primární rolí byla alokace úspor a financování investičních projektů v relativně geograficky uzavřených společenstvích. Tato jistá geografická uzavřenost s sebou nesla podstatnou výhodu v podobě informací. Finanční instituce si byly vědomy hospodářské situace a potřeb lidí. S touto funkcí bylo spojeno též kvalitativně naprosto odlišné prizma, které se na bankéře aplikovalo po 2. světové válce, než jakým je na „bankéře“ nahlíženo nyní - jako na odtržené od životů „běžných lidí“. V rámci výkladu autor ilustruje, jak se s rozšiřováním globalizace a reorientace bank na velké investiční projekty zpřetrhala vazba mezi př́jemci depozit a jejich vkladateli. Tento vývoj umožnil genezi mezinárodního obchodu a finančních trhů, které usnadnily přesuny velkých objemů kapitálu napříč národními trhy. Z velké části tato dynamika měla podnět v ,regulaci Q“, která znemožňovala americkým bankám úročit běžné vklady. Jeho výsledkem bylo ukládání těchto depozit u evropských bank, které poté tyto prostředky zapůjčily zpětně svým americkým protějškům. Banky nyní již nefinancovaly potřeby lidí, v jejichž prostředí fungovaly, nýbrž hledaly nejziskovější trhy. Tato změna se odrazila v požadavcích na vyhledávané pracovníky ze strany bankovních domů - reorientace z jedinců, jež byli součástí společenství a rozuměli obchodu a lidem, kterým poskytovali služby, na ,absolventy prestižních univerzit držících doktorské tituly z matematiky či fyziky“.

Dle názoru autora cíl nejlepšího uspokojení zákazníka byl zaprodán krédu co možná největších obchodů a největšího množství transakcí. Jedna z částí kapitoly zdařile popisuje, jak za vznikem finančních derivátů stály pokusy o regulatorní arbitráž a životní zkušenosti autora, který byl jejich svědkem. Kritiky není ušetřen ani vývoj ratingových agentur, jež se přesměrovaly z poskytování služeb investorům na samotné emitenty. Závěrem stojí za zmínku autorův vhled do změny nahlížení „,bankéřü“ na problém 
rizika. Zatímco „bankéři“ v poválečném období nepočítali se ztrátami a snažili se jim předejít, dnešní (finanční) svět pracuje s „kvantifikovatelným“ rizikem ztráty, viz model Value-at-Risk.

Způsob percepce a „nakládání“ s rizikem je předmětem kapitoly druhé. Autor si popisem „sebegratulace“ ze strany amerických regulátorů ve vztahu k (domnělé) vy̌šší obecné odolnosti finančního systému vůči riziku, dosažené (mezi)národní diverzifikací, připravuje kritiku jejich krátkozrakosti a především ideologických kořenů, které nalezly svoji oporu v ekonomické teorii efektivních trhů, racionálních očekáváních a v neoklasické ekonomii obecně. Text uvádí zajímavou skutečnost o počátcích slavného Capital Asset Pricing Model (CAPM), jenž byl původně odmítnut k publikaci $\mathrm{v}$ Journal of Finance, nebot' předpoklady modelu, jak napsal jeden z oponentů, byly „absurdně nereálné“. ${ }^{1}$ Obecné provázanosti tehdejší a do jisté míry i dnešní ekonomie hlavního proudu s politickou rovinou je věnována celá jedna pasáž. Chybné předpoklady teorie racionálních očekávání jsou ilustrovány na „faktu“, že většina investorské veřejnosti nevěděla a mnohdy ani nebyla schopna pochopit komplexnost mnohých finančních derivátů, jakými jsou např́klad collateralized debt obligation (CDO) nebo credit default swap (CDS). Autor popisuje, jak legislativní ukotvení CDS ve Velké Británii nebylo náhodné, nebot’ britské právo $\mathrm{v}$ tehdejší době umožňovalo zasazení do „legislativního vakua“, jelikož derivát nebyl chápan ani jako pojištění či sázka na výsledek. Kapitola je ukončena tvrzením, že finanční svět včetně pojistného odvětví je odtržen od „reality běžných lidí“ a žádným způsobem nepřispívá $\mathrm{k}$ potřebám společnosti. Tento motiv se opakovaně objevuje na mnoha místech v celé publikaci.

Kapitola třetí a čtvrtá spolu úzce souvisejí, nebot' se zabývají problematikou zprostředkování a iluzorní ziskovosti především investičních bankovních domů. Expozice začíná zdrcující kritikou hlavní mantry financí - transparentnosti. Autor brilantní argumentací ukazuje, že potřeba maximální transparentnosti je znakem skutečnosti, že se jí ve skutečnosti nedostává, a trhy obecně i ve spojení s „běžnými lidmi“ jsou v kontinuálním stavu nedůvěry. V tomto smyslu by se dalo hovořit o jistém ,paradoxu transparentnosti“. Kritika plynule přechází k dalšímu krédu finančních trhů, jmenovitě k potřebě co možná nejvyšší likvidity a dnes již „tradičnímu“ postulátu, že „trhy diskontují vše“. Úsměvné tvrzení o „mluvících hlavách na CNBC“, které komentují, co si „trhy myslí“, funguje jako odraz záměny znalostí za „vedení davu“. Požadavek nejvyšší možné likvidity je potřebou a zároveň cílem (finančních trhů) sám o sobě; opět bez jakékoliv přidané hodnoty k potřebám široké společnosti. Tuto skutečnost ilustruje na relativní irelevantnost primárních trhů $\mathrm{v}$ porovnání s trhy sekundárními. Kritika pokračuje rozdílnou dynamikou v chování tržních účastníků v krátkém a dlouhém období. V dlouhém období ceny finančních produktů odrážejí jejich fundamentální základ, zatímco v období krátkém zaleží pouze na tom, jak přesně lze odhadnout „,chování davu“. S touto kritikou souvisí i tvrzení o perverzní nutnosti „nové, neočekávané informace“, které se emitenti snaží dostát. V úzké návaznosti se autor zaobírá vysokofrekvenčním obchodováním, jenž tvoří téměř polovinu všech transakcí. Argumentuje, že tento v současnosti preferovaný způsob provádění obchodů neposkytuje žádnou přidanou informaci o fundamentech determinujících ceny aktiv. Kapitola čtvrtá je ukončena znamenitou ukázkou „firemní

1 Není bez zajímavosti, že článek byl publikován poté, co se autor W. Sharpe zaštítil pozitivní metodologií M. Friedmana - důsledky teorie jsou důležité, nikoliv její předpoklady; též se mezitím obměnila editorská rada časopisu. Avšak tuto informaci v samotné knize nenalezneme. 
kultury“ investičních domů, jejichž zaměstnanci i de facto celá firemní filozofie se točí okolo maximalizace zisku v krátkém období. Kritiky nejsou ušetřeny ani metody mark-to-market a mark-to-model. Autor graficky a statisticky dokládá, že vysoká ziskovost především investičního bankovnictví je chimérou par excellence; tratícími jsou pouze akcionáři, vysoké ziskovosti dosahují pouze nejvýše postavení zaměstnanci. Kapitola poskytuje velmi kvalitní pohled na způsob myšlení nejvýše postavených zaměstnanců. Zdálo by se to jako klišé, že citovaní jsou do jednoho bývalí, avšak velmi movití zaměstnanci zkrachovalých či de facto zestátněných bankovních domů. Pomyslnou třešničkou na dortu je vyhodnocení zavádějícího ukazatele return-on-equity (ROE) a jeho naprosté nedostatečnosti vzhledem ke snaze o jeho „umělou“ maximalizaci pomocí zpětného odkupu emitovaných akcií.

Kapitola pátá až sedmá tvoří druhou část knihy pojednávající v detailu o funkcích, jež by finanční zprostředkovatelé a finanční trhy měly obecně zajištovat. Mapuje genezi proměny specializovaných institucí, financujících především výstavbu bytového zázemí a infrastruktury, v mezinárodní finanční domy. Argumentace se nese v duchu negativních důsledků prodloužení řetězce zprostředkování, ve kterém se ztrácí a snižuje informační hodnota jak pro střadatele, tak i finanční zprostředkovatele. Obecným tématem je „zvrácenost“ motivace prodeje co největšího množství hypoték nedostatečně bonitním zákazníkům z důvodu obrovské poptávky po investičních instrumentech, které byly kryty právě těmito (nekvalitními) hypotečními úvěry. Jeden z důvodů, které autor identifikuje ve špatné činnosti ratingových agentur, jež investičním instrumentům přisuzovaly vyšší hodnocení než samotným podkladovým aktivům, byla jejich provázanost s emitenty. Agentury nehodnotí v zájmu potenciálních investorů, ale aktivně spolupracují s emitenty, kteří tvoří nezanedbatelnou část jejich př́ijmů. Autor je toho názoru (jenž je podložen vynikající argumentací a empirickým pozorováním), že kapitálové trhy zdaleka neplní funkci alokace kapitálu, ale především umožňují regulatorní a daňovou arbitráž ze strany nadnárodních společností.

Následuje popis fungování tzv. kanálu depozit. Př́íjemci depozit, tj. banky obecně, jsou ve výjimečném postavení. Autor ukazuje, jak velká část bankovních pasiv tvořených depozity („,cizími penězi“) umožňuje těmto institucím provádět vysoce rizikové derivátové transakce a udržovat nereálně vysoké finanční páky, nebot' svojí de facto kontrolou platebních a zúčtovacích systémů (spolu s držbou „cizích peněz“) mají implicitní státní záruky. Konečné konstatování je veskrze negativní, nebot’ hlavní činností soudobých zprostředkovatelů není zdaleka financování „reálných“ investičních projektů.

Vedle depozitního kanálu je identifikován tzv. investiční kanál, v jehož rámci by zprostředkovatelé měli svým klientům hledat ziskové investiční prŕiležitosti a zároveň provádět zodpovědnou správu svěřeného majetku či bohatství. V této kapitole autor navazuje na svoje tvrzení o jistém zpřetrhání dlouhodobého vztahu mezi zprostředkovateli a jejich zákazníky, nebot' profesní filozofie se kvalitativně posunula k tlačení klientů k provádění co největšího počtu a objemu transakcí, jelikož tímto způsobem zprostředkovatelé inkasují své poplatky a bonusy. Ruku v ruce s tímto vývojem jde obecná ztráta důvěry mezi jednotlivými tržními účastníky, viz diskutovaná potřeba transparentnosti.

Poslední část knihy je z pohledu zkoumané problematiky nejdůležitější. Postupně přináší kritické zhodnocení regulace finančního odvětví obecně, jeho úzké provázanosti nejen na (hospodářskou) politiku, ale též na akademickou sféru a návrhy na změny v regulatorní činnosti. Bohužel do jisté úrovně některé pasáže této části jsou duplicitní 
s předešlým výkladem. $V$ osmé kapitole autor shrnuje svůj postoj vůči provádění regulatorních funkcí ze strany pověřených institucí. Nicméně uvádí zajímavé skutečnosti, které stály za zavedením basilejských regulatorních požadavků. Podrobuje ostré kritice soudobé způsoby regulace kapitálových trhů a jejich kontraproduktivní důsledky, především co se týká (zbytečných) nákladů, které jsou uvaleny na tržní účastníky. Autor přechází od kritiky fungování kapitálových trhů, jejichž cílem by mělo být poskytování informací o hodnotě aktiv, nikoliv o jejich ceně tak, jak je tomu nyní, k negativnímu hodnocení kontinuální záměny (dostupných) dat za fundamentální informace. Využívá „paradoxu transparentnosti“", aby ukázal skutečnost, že regulatorní požadavky nutí subjekty k publikování obrovského množství informací s diskutabilním přínosem, které zároveň zahlcují a znesnadňují identifikaci informací relevantních. Své postoje zakončuje tvrzením, že regulace jakéhokoliv trhu a především trhu, jenž pracuje s ,cizími penězi“, by měla cílit na morální integritu jeho členů, nikoliv na integritu trhu samotného. Diskuse se přenáší $\mathrm{k}$ faktické (ne)schopnosti vykonávat regulatorní funkce, nebot' instituce jimi pověřené nejsou schopny konkurovat finančním domům co do finančního ohodnocení nejlepších, perspektivních pracovníků - toto je jeden z mnoha uvedených př́kladů negativního „vysávání“ nejschopnějších lidí do finanční sféry, lidí, jež by mohli uplatnit své nadprůměrné schopnosti $\mathrm{v}$ „reálném“ hospodářství. $\mathrm{S}$ tím úzce souvisí dnešní obecná personální provázanost regulovaných, regulátorů a v neposlední řadě akademické sféry. Autor vyslovuje částečně doložené tvrzení, že část akademické obce v oblasti nejen finanční ekonomie de facto pracuje $\mathrm{v}$ žoldu bankovních institucí financujících jejich výzkumnou činnost. Spolu s využitím ekonomie hlavního proudu jako ideologického základu pro ospravedlnění politických rozhodnutí vytváří tato kombinace půdu pro neformální nedotknutelnost či vyšší postavení finančního odvětví oproti odvětvím „běžným“. Autor též dokládá, že největší finanční domy patří mezi subjekty alokující nejvíce finančních zdrojů na lobbing na všech úrovních státní správy.

Kapitola devátá o národohospodářské politice pojednává o provázanosti monetární ekonomie a reálného hospodářství. Text poskytuje zdařilou interpretaci geneze provádění měnové politiky ve prospěch finančních trhů. Podrobuje velmi ostré kritice institut „věřitele poslední instance“ a hodnotí tzv. kvantitativní uvolňování veskrze negativně, nebot’ dle jeho názoru dochází $\mathrm{k}$ masivnímu přerozdělení bohatství napříc generacemi. Polemicky se zamýšlí nad prováděním měnové politiky v závislosti na tom, „,co si bude myslet trh“. Kapitola je zakončena diskusí problematického vykazování příspěvku finančního sektoru $\mathrm{k}$ hrubému domácímu produktu spolu s „amorálností“ některých finančních domů, jež provádějí obchody s diktátory a pochybnými osobami obecně.

Kapitoly desátá a poslední, jedenáctá, shrnují hlavní body dosavadní kritiky. Autor poskytuje velmi zajímavou analogii mezi způsobem regulace a navržením národních rozvodných sítí vůči možnému uspořádání finančního sektoru. Velká část této sekce patří diskusi o problematice střetu zájmů a obecně velmi rozmělněné zodpovědnosti a odpovědnosti za „cizí peníze“. Navrhované body reformy si zaslouží jejich vyjmenování: (1) obnovení krátkých, př́ímých vazeb v rámci finančního zprostředkování; (2) obnovení specializovaných institucí, jež budou z (dlouhodobých) depozit financovat investiční projekty přímo spojené s daným společenstvím, a jejich oddělením od institucí, které provádějí aktivní, „,predátorské“ obchody; (3) vyžadovat od pracovníků disponujících s „cizími penězi“ chování, které se slučuje se základními myšlenkami loajality a zodpovědné správy vůči jejich klientům; (4) zavedení trestních a občansko-právních 
postihů jednotlivců, především těch nacházejících se na nejvyšších pozicích; (5) nakládat $\mathrm{s}$ finančním odvětvím jako s jakýmkoliv jiným, veškeré explicitní i implicitní záruky by měly být zrušeny, včetně institutu „věřitele poslední instance“; (6) ustat ve využívání finančního sektoru jako nástroje národohospodářské politiky, přistupovat k názorům subjektů v tomto odvětví se stejným, umírněným postojem jako u zbytku ekonomické společnosti. Výčet popisuje filozofii stojící za způsobem, jakým by se měla finanční sféra změnit, avšak jedno doporučení si zaslouží pár dodatečných slov. Jmenovitě se jedná o osobní trestní odpovědnost nejvyšších zaměstnanců finančních institucí za prohřešky, jichž se dopustí jejich podřizení, tj. aplikace principu, jež se využíval nejen v námořní dopravě - co se stane během vaší hlídky, je vaší odpovědností a nesete veškeré důsledky. Tímto způsobem by se zabránilo ,alibistickému“ chování finančních domů, které se „distancují“ od chyb jednotlivců. Spolu s tím by se zamezilo zvrácenému prŕístupu především investičních domů, považujících uvalené pokuty za součást provádění obchodů, kdy náklady přirozeně nesou akcionáři, nikoliv zaměstnanci, při jejichž „hlídce“ došlo k porušení (nejen) regulatorních pravidel.

Profesor John Kay ve své velmi rozsáhlé a detailní kritice nenechá nit suchou na fungování prakticky žádné z úrovní finančního systému. Z pohledu (především monetární) ekonomické teorie mají předložené návrhy na reformu velmi blízko zejména $\mathrm{k}$ doporučením postkeynesovkého myšlenkového proudu (zvláště u jeho radikálnější větve $)^{2}$ a v menší míře též u učení ,rakouských“ ekonomů. Nicméně autor se nikde ekonomickou teorií nezaštit’uje, nejspíše z praktických důvodů, aby byla přístupná i „,běžným lidem“. Nejedná se o úzce specializovaný text, který by byl cílen na akademické a vědecké pracovníky. Tomuto je do jisté míry i podřizena autorova stylistika a syntaxe. Přestože je autor rodilým Skotem, nevyužívá gramatických nebo idiomatických tvarů přirozeně spjatých s britskou angličtinou; text je řazen do relativně jednoduchých, snadno srozumitelných souvětí.

Je zřetelně vidět, že autorovo myšlení se důsledně drží neoklasické dichotomie rozdělující „peněžní“ a „reálné“ sféry hospodářství, avšak v její aplikaci, dle názoru autora této recenze, dochází př́liš daleko. S finanční sférou zachází jako se světem, jenž je dán „realitě“ ekonomiky shůry, jakoby snad stála mimo či nad „,reálným“ nefinančním světem. Poté přirozeně stačí pouze malý krok k „démonizování“ bankéřů a finančníků, kteří jako bájné bytosti uzurpují „,skutečné“ hodnoty vyprodukované „,běžnými lidmi“. Avšak zde leží největší nebezpečí pro toto dílo, tedy aby nebylo časem zařazeno mezi další populárně naučné publikace, jež využívají nynější aktuálnost a kontroverznost zkoumané problematiky. Návrhy reforem mají silně „,individualistický“ charakter, snaží se identifikovat jednotlivce, skutečné viníky. S vědomím jisté nekorektnosti by se dalo hovořit o aplikaci metodologického subjektivismu, který je tak nerozlučný s neoklasickou ekonomií. Přesto autor v její aplikaci není důsledný, nebot’ jeho chápání ,ppeněžní“ sféry mu neumožňuje, resp. z knihy není žrejmý opak, uchopit očividný fakt, že finanční instituce fungují v rámci většího systému, který na své členy uvaluje explicitní a implicitní normy chování a vykonávání činnosti. Subjekty v tomto prostoru vždy konají přesně to, co jim systém umožní. Svalování veškeré viny na chamtivé, všehoschopné bankéře není ani korektní ani neleží ve vyšší „,morální dimenzi“. Je důležité zdůraznit, že takovéto nahlížení není v žádném prrípadě fenoménem, jenž by byl spojen pouze s naší epochou. Před

2 Avšak v pohledu na roli i samotnou existenci institutu „věřitele poslední instance“ se diametrálně liší. 
téměř 90 lety se F. A. Hayek ostře vymezil vůči totožné identifikaci bank jako „viníkư““ způsobujících hospodářské cykly a označil ji za nesmyslnou. Autor jakoby zapomíná, ačkoliv tuto skutečnost sám uvádí, že to byla právě obrovská poptávka po hypotečních úvěrech ze strany jeho „běžných lidí“, která zavdala příčinu k vysoké finanční spekulaci. A tato poptávka byla z velké části tažena spekulací, jež nebyla o nic méně chamtivá, než chamtivost „amorálních finančníků“. Dovedeno do důsledku, autor pojímá své „běžné lidi“ jako děti, které nejsou schopny uvědomit si důsledky svých činů a jsou odkázány na vedení svými poručníky. Opak je pravdou a paralela mezi Marxovou teorií vykořist'ování proletariátu chamtivými, všehoschopnými kapitalisty je více než zřejmá. Nastíněná polemika se však týká „,pouze“ způsobu, jakým autor nahlíží na interakci mezi „,běžnými lidmi“" a „bankéŕi“, nikterak nesnižuje bezpochyby vysokou přidanou hodnotu recenzované knihy $\mathrm{k}$ diskusi problematiky reformování finančních trhů a institucí. 